\title{
Verschillen in zorggebruik onder zelfstandig wonende 55-plussers van verschillende herkomst
}

\author{
Maaike den Draak · Debbie Verbeek-Oudijk
}

Published online: 10 November 2020

(c) The Author(s) 2020

\begin{abstract}
Samenvatting De groep senioren met een niet-westerse migratieachtergrond zal de komende jaren zowel in absoluut aantal als in relatief aandeel toenemen. Onderzocht is of zelfstandig wonende 55-plussers met een niet-westerse achtergrond (Turks, Marokkaans, Surinaams of Antilliaans) in hun gebruik van langdurige zorg (thuiszorg en informele hulp) verschillen van 55-plussers met een Nederlandse herkomst. De gegevens die zijn verzameld betreffen de periode van februari 2014 tot half juli 2015, dus rondom de stelselwijziging van 1 januari 2015. Wanneer rekening wordt gehouden met samenstellingseffecten, dan ontvangen senioren met een migratieachtergrond even vaak zorg als autochtone Nederlandse. Herkomst blijkt echter wel samen te hangen met de bron van de hulp wanneer senioren hulp ontvangen. Zowel Turkse, Marokkaanse als Antilliaanse 55-plussers ontvangen vaker (enkel) informele hulp dan autochtone 55-plussers. Het lijkt erop dat zij de weg naar professionele thuiszorg niet in gelijke mate weten te vinden als 55plussers met een Nederlandse achtergrond. Zorgaanbieders en gemeenten moeten actief stappen ondernemen om de toegankelijkheid van de zorg voor deze groepen te verbeteren. Daarbij is het belangrijk om te weten dat senioren met een migratieachtergrond vaak al op jongere leeftijd met fysieke beperkingen en een slechtere gezondheid te maken krijgen en daardoor mogelijk eerder in aanmerking moeten komen voor professionele ouderenzorg.
\end{abstract}

Trefwoorden senioren - niet-westerse migranten zorggebruik · thuiszorg · informele zorg

M. den Draak ( $\varangle) \cdot$ D. Verbeek-Oudijk

Sociaal en Cultureel Planbureau, Den Haag, Nederland m.den.draak@scp.nl

\section{Differences in care use among independently living over-55s of native and non-Western origin}

\begin{abstract}
The group of seniors with a non-Western migration background will continue to increase in both absolute and relative terms. This study aims to determine whether over-55s with a non-Western background (Turkish, Moroccan, Surinamese or Antillean) who live independently differ in long-term care use (home care and informal care) from Dutch over-55s. We used data from February 2014 to mid-July 2015, around the time the Dutch long-term care system was reformed. When the population composition is taken into account, over-55s with a migration background are as likely to receive care as their native peers. However, origin is associated with the source of the help for those who receive help. Turkish, Moroccan as well as Antillean over-55s are more likely to receive (solely) informal help compared to native Dutch peers. They seem to be unable to find their way to professional home care to the same extent as over-55s with a Dutch background. Care providers and municipalities have to actively take steps to improve the accessibility of care for these groups. It should also be noted that seniors with a migration background often experience physical disabilities and poorer health at a younger age and may need earlier access to professional elderly care.
\end{abstract}

Keywords Aged · Ethnic groups · Caregivers · Home care services $\cdot$ Home nursing

\section{Inleiding}

Nederland vergrijst en onze niet-westerse migranten vergrijzen mee. In 2019 is een op de zeven van de niet-westerse migranten 55 jaar of ouder, in $2035 \mathrm{zal}$ dat bijna een kwart zijn. Daarmee zal het aantal 55- 
plussers met een niet-westerse achtergrond binnen twintig jaar meer dan verdubbelen van circa 333.000 in 2019 tot ruim 693.000 in 2035. Dat betekent dat in 2035 een op de tien 55-plussers een niet-westerse achtergrond heeft, terwijl dat nu nog $6 \%$ is (bewerking van gegevens van CBS StatLine, januari 2020).

Senioren en ouderen met een niet-westerse achtergrond hebben doorgaans een slechtere gezondheid en meer fysieke beperkingen dan 55-plussers zonder migratieachtergrond [1-5]. Ze zijn daardoor eerder 'oud' of kwetsbaar. Tegelijkertijd laten diverse bronnen zien dat senioren van niet-westerse herkomst, in het bijzonder die van Turkse en Marokkaanse herkomst, minder gebruikmaken van professionele thuiszorg dan senioren van Nederlandse herkomst, ook wanneer rekening wordt gehouden met verschillen in gezondheid [1, 6-9]. Een Deens onderzoek laat vergelijkbare resultaten zien [10]. Turkse en Marokkaanse senioren ontvangen wel vaker hulp van familieleden en andere bekenden [1, 6]. Daarentegen lijken senioren met een Surinaamse, Antilliaanse of Molukse herkomst in hun hulpgebruik meer op autochtone senioren $[1,7]$.

In de literatuur worden meerdere redenen genoemd voor het relatief beperkte gebruik van professionele thuiszorg door oudere, niet-westerse migranten. Onder meer taalproblemen, analfabetisme en beperkte gezondheidsvaardigheden zouden een rol spelen, in combinatie met een gebrekkige kennis van het Nederlandse zorgsysteem en onbekendheid met de thuiszorg en de bijbehorende aanvraagprocedures [1, 4, 6-8, 11-14]. Sommige senioren met een migratieachtergrond vinden het minder vanzelfsprekend om thuiszorg aan te vragen [8]. Zij ontvangen, verwachten of prefereren hulp van de familie of menen dat hun problemen onvoldoende ernstig zijn om thuiszorg te ontvangen $[1,4,6-8,11,13,14]$. Soms wachten ze af totdat de huisarts, hun kind of de thuiszorg hulp aanbiedt of regelt [8]. Daarnaast kunnen een negatief beeld van de thuiszorg en de verwachting van hoge kosten voor de zorg een drempel vormen $[4,6,8,12]$. Ook zou het zorg- en ondersteuningsaanbod niet goed aansluiten bij de behoeften van migrantensenioren en hun mantelzorgers $[4,6,8,12$, 14].

De genoemde Nederlandse onderzoeken naar etnische verschillen in het gebruik van langdurige zorg (thuiszorg en informele hulp) door zelfstandig wonende senioren zijn veelal gedateerd. De gegevens komen uit de periode 1999-2012 [1, 6-9]. Sindsdien hebben zich vele veranderingen in de samenleving en langdurige zorg voltrokken. Zowel het aantal als het aandeel senioren met een niet-westerse achtergrond nam toe. Daarnaast ging het zorgstelsel flink op de schop. In 2007 werd de eerste Wet maatschappelijke ondersteuning (Wmo) ingevoerd. De Hervorming Langdurige Zorg (HLZ) kreeg vanaf 1 januari 2015 gestalte door de afschaffing van de Algemene Wet Bijzondere Ziektekosten (AWBZ), het onderbrengen van de wijkverpleging in de Zorgverzekeringswet (Zvw) en de invoering van de Wmo 2015 en de Wet langdurige zorg (Wlz) [15].

Eigen verantwoordelijkheid en zo lang mogelijk zelfstandig wonen zijn centrale uitgangspunten van het Nederlandse zorgbeleid. Het is daarbij van belang om in de gaten te houden of ook meer kwetsbare groepen, zoals senioren met een niet-westerse achtergrond, de zorg en ondersteuning ontvangen die zij nodig hebben. Zowel burgers als professionals vinden het in het huidige - complexe - zorgstelsel soms lastig om de weg te vinden naar de juiste zorg en ondersteuning $[15,16]$. Het is aannemelijk dat senioren met een migratieachtergrond dit ook zo ervaren, mogelijk in een nog sterkere mate, waardoor zij weinig gebruikmaken van professionele thuiszorg. Tegelijkertijd zijn er signalen dat de traditionele relaties in migrantenfamilies veranderen en dat de familiezorg verschuift naar zorg die met professionals gedeeld wordt [14, 17, 18]. Ook de arbeidsparticipatie van vrouwen en de beheersing van de Nederlandse taal namen toe onder niet-westerse migrantengroepen [19].

Het is dus hoog tijd om naar meer recente gegevens te kijken. Dit onderzoek heeft als doel te kijken of 55plussers met een niet-westerse herkomst ten tijde van de hervorming van de langdurige zorg verschillen in hun gebruik van thuiszorg en informele hulp van 55plussers met een Nederlandse herkomst.

Herkomst is slechts een van de vele factoren die van invloed kunnen zijn op het zorggebruik van een persoon. De determinanten van zorggebruik zijn uitgebreid beschreven in het veel toegepaste theoretische model van Andersen en collega's en in de opvolgers daarvan [20-22]. Naast sociaal-maatschappelijke factoren (zoals vergrijzing en normen en waarden) en factoren van het zorgsysteem (bijvoorbeeld het zorgaanbod en regels met betrekking tot indicatiestellingen) zijn individuele kenmerken van invloed op het zorggebruik. Het model categoriseert de individuele kenmerken die van invloed zijn op het zorggebruik in: a) de behoefte aan zorg bepaald door de gezondheidstoestand en de aanwezigheid van functiebeperkingen (need factors); b) situationele factoren of hulpbronnen die het gebruik van zorg mogelijk maken of belemmeren (enabling factors), zoals de financiële middelen en de aanwezigheid van huisgenoten die kunnen helpen; en c) persoonskenmerken die bijdragen aan de geneigdheid tot zorggebruik (predisposing factors), zoals leeftijd, geslacht en herkomst. Onderzoek toont aan dat het gebruik van professionele extramurale zorg in Nederland samenhangt met gezondheidskenmerken als fysieke beperkingen en chronische aandoeningen, leeftijd, geslacht, herkomst, samenstelling van het huishouden, inkomen en opleidingsniveau [23].

De onderzoeksvragen in dit onderzoek zijn dan ook de volgende:

- Verschilt het gebruik van langdurige zorg (thuiszorg en informele hulp) door zelfstandig wonende 
55-plussers met een niet-westerse achtergrond in mate en bron van dat van zelfstandig wonende 55plussers van Nederlandse herkomst?

- Blijven deze verschillen bestaan wanneer rekening wordt gehouden met andere determinanten (gezondheidskenmerken, persoonskenmerken, hulpbronnen) van het gebruik van langdurige zorg?

\section{Methode}

\section{Databron en onderzoekspopulatie}

De geanalyseerde gegevens zijn afkomstig van de Survey Integratie Migranten uit 2015 (SIM'15). Deze survey is gehouden in de periode van februari tot half juli 2015 onder zeven etnische groepen, waaronder Turkse, Marokkaanse, Surinaamse en Antilliaanse Nederlanders, en een autochtoon Nederlandse vergelijkingsgroep. De onderzoekspopulaties bestaan uit in Nederland wonende personen van vijftien jaar en ouder die geregistreerd staan in de Basisregistratie Personen (BPR). Het Centraal Bureau voor de Statistiek (CBS) heeft voor iedere herkomstgroep de steekproef getrokken en trok daarbij eerst steekproeven van gemeenten. De gegevens zijn verzameld met een sequentiële mixed mode-benadering: in eerste instantie via een webenquête, waarna een face-to-face-benadering met tweetalige interviewers werd ingezet. De Nederlandse vragenlijst was vertaald in het Turks en het Marokkaans-Arabisch. De behaalde responspercentages varieerden van $45 \%$ onder de Surinaamse Nederlanders tot $57 \%$ onder de autochtone Nederlanders. Voor het bestand zijn weegfactoren van het CBS beschikbaar om afwijkingen in de nettosteekproef in vergelijking tot de populaties te corrigeren. Bij het aanmaken van de weegfactoren is niet apart gekeken naar de leeftijdsgroep 55-64 jaar, wel naar 35-64 jaar en 65-plus. Onder de respondenten met een Marokkaanse achtergrond zijn 65-plussers iets ondervertegenwoordigd. We hebben de weegfactoren van het CBS gebruikt. Daarmee is gecorrigeerd voor verschillen in geslacht, leeftijd, generatie (eerste of tweede), type van het huishouden, grootte van het huishouden, gemeentegrootte en persoonlijk inkomen in combinatie met herkomst. Meer informatie is te vinden in het SIM'15-verantwoordingsrapport [24].

Voor het hier beschreven onderzoek gebruikten we de gegevens van personen van 55 jaar en ouder met een Turkse, Marokkaanse, Surinaamse, Antilliaanse of autochtoon Nederlandse achtergrond. Het gewogen databestand bevat de volgende aantallen personen: 129 Turkse, 157 Marokkaanse, 253 Surinaamse, 198 Antilliaanse en 415 autochtone Nederlandse 55-plussers. (Het ongewogen databestand bevat de volgende aantallen: 127 Turkse, 129 Marokkaanse, 256 Surinaamse, 205 Antilliaanse en 420 autochtoon Nederlandse 55-plussers.)

\section{Variabelen en analyse}

In dit onderzoek zijn we geïnteresseerd in verschillen in zorggebruik van 55-plussers van verschillende herkomst. De uitkomstmaat zorggebruik is gemeten aan de hand van de vraag of iemand in de voorafgaande twaalf maanden hulp of zorg heeft gekregen vanwege zijn of haar gezondheid. Daarbij is aangegeven dat medische hulp van dokters niet wordt bedoeld en werden als voorbeelden aankleden, douchen, boodschappen doen, koken en schoonmaken genoemd. De antwoordcategorieën waren: 1) ja, van familie, vrienden en bekenden, 2) ja, van een professionele hulp, zoals de thuiszorg of een werkster en 3) nee. Respondenten konden slechts één antwoord kiezen. Omdat de eerste twee categorieën elkaar in de realiteit niet uitsluiten, nemen we aan dat respondenten die zowel professionele als informele hulp ontvangen bij het beantwoorden van de vraag hebben aangegeven dat zij professionele hulp ontvangen. Onder de mate van zorggebruik verstaan we het wel of niet ontvangen van hulp. Met de bron van zorggebruik bedoelen we of de respondent professionele (en mogelijk informele) zorg ontvangt of (enkel) informele zorg.

De fysieke en de psychische gezondheid zijn gemeten met de SF-12, een internationaal gebruikte standaardlijst die uit twaalf vragen bestaat [25]. De vragen schetsen een beeld op acht gezondheidsdimensies, waarbij vier dimensies betrekking hebben op de fysieke gezondheid (fysiek functioneren, fysieke rolbeperkingen, lichamelijke pijn en algemene gezondheidservaring) en vier op de psychische gezondheid (sociaal functioneren, emotionele rolbeperkingen, geestelijke gezondheid en vitaliteit). In SIM'15 wijkt de formulering van de vragen en antwoorden enigszins af van de originele SF-12 om een beter begrip door de respondenten te bereiken. De gebruikelijke normering kan daarom niet toegepast worden. De constructie van de SF-12 in dit onderzoek volgt daarom Andriessen en collega's, die eerder met de data werkten [26]. De resulterende SF-12-scores op fysieke gezondheid en psychische gezondheid hebben een theoretische spreiding van 1 tot en met 100 , waarbij een hogere waarde een betere gezondheid aangeeft.

De persoonskenmerken (predisposing factors) in het onderzoek zijn: herkomst, leeftijd (in drie categorieën: 55-64 jaar, 65-74 jaar en 75 jaar of ouder), geslacht en opleidingsniveau. Het opleidingsniveau betreft het hoogste tot nu toe behaalde diploma. De hulpbronnen (enabling factors) in het onderzoek zijn: inkomen en alleenwonend of niet. De gegevens over inkomen betreffen registratiegegevens die door het CBS aan het databestand zijn gekoppeld. Het gaat om het besteedbare huishoudinkomen in percentielen in 2013; recentere gegevens zijn helaas niet beschikbaar. De inkomensgegevens zijn vervolgens in kwartielen ingedeeld. Het besteedbare huishoudinkomen bestaat uit het bruto-inkomen van alle leden van het 
Tabel 1 Hulp of zorg gekregen vanwege gezondheid in de voorafgaande twaalf maanden, naar herkomst, personen van 55 jaar en ouder, 2015 (horizontaal gepercenteerd) ${ }^{a}$

\begin{tabular}{|c|c|c|c|c|c|}
\hline & $\begin{array}{l}\text { Ja, van } \\
\text { familie en } \\
\text { bekenden }\end{array}$ & $\begin{array}{l}\text { Ja, van een } \\
\text { professio- } \\
\text { nele hulp }\end{array}$ & Nee & Totaa & $\begin{array}{l}\text { Significant }{ }^{b} \text { ver- } \\
\text { schil met } 55 \text {-plus- } \\
\text { sers van herkomst }\end{array}$ \\
\hline $\begin{array}{l}\text { Turks } \\
(n=126)\end{array}$ & 21 & 13 & 66 & 100 & A, NL \\
\hline $\begin{array}{l}\text { Marokkaans } \\
(n=155)\end{array}$ & 23 & 8 & 69 & 100 & $\mathrm{~S}, \mathrm{~A}, \mathrm{NL}$ \\
\hline $\begin{array}{l}\text { Surinaams } \\
(n=252)\end{array}$ & 12 & 15 & 74 & 100 & $\mathrm{M}, \mathrm{A}$ \\
\hline $\begin{array}{l}\text { Antilliaans } \\
(n=198)\end{array}$ & 11 & 7 & 82 & 100 & $\mathrm{~T}, \mathrm{M}, \mathrm{S}$ \\
\hline $\begin{array}{l}\text { Autochtoon } \\
\text { Nederlands } \\
(n=415)\end{array}$ & 9 & 11 & 80 & 100 & $\mathrm{~T}, \mathrm{M}$ \\
\hline \multicolumn{6}{|c|}{$\begin{array}{l}\text { a Pearson's chi-kwadraat }=37,1, p \text {-waarde }=0,0001 \\
\text { b } P \leq 0,05 \\
\text { ' } A \text { Antilliaans, NL autochtoon Nederlands, } S \text { Surinaams, } M \text { Marokkaans, } \\
\text { TTurks } \\
\text { Bron: SCP/CBS (SIM'15), gewogen gegevens }\end{array}$} \\
\hline
\end{tabular}

huishouden gezamenlijk, verminderd met betaalde inkomensoverdrachten (bijvoorbeeld alimentatie), premies inkomensverzekeringen (zoals premies verzekeringen in verband met arbeidsongeschiktheid), premies ziektekostenverzekeringen en belastingen op inkomen en vermogen (website CBS).

De verschillen in het zorggebruik en in individuele kenmerken tussen de ouderen met verschillende migratieachtergronden zijn eerst bivariaat getoetst (zie tab. 1 en 2) met behulp van Pearson's chikwadraattoets $(p<0,05)$ en voor continue variabelen (leeftijd, SF-12scores) met regressieanalyses $(p<0,05)$. Om inzicht te krijgen in de samenhang tussen de mate van het zorggebruik, de zorgbron en de individuele kenmerken, waaronder herkomst, is het sequentiële logit-model toegepast (zie tab. 3). Het model omvat twee stappen: 1) het wel of niet gebruiken van hulp en 2) wanneer hulp ontvangen wordt, het gebruik van professionele hulp of hulp van familie of vrienden. Het model voorspelt de beide stappen simultaan op grond van een aantal persoons- en gezondheidskenmerken, waaronder herkomst, en enkele hulpbronnen. Er is gekeken naar de kansen in oddsratio's, waarbij een 95\%betrouwbaarheidsinterval (BI) is gehanteerd $(p<0,05)$. Een oddsratio (OR) groter dan 1 betekent een grotere kans op de gebeurtenis in vergelijking tot de referentiegroep. De analyses zijn uitgevoerd in Stata 16.

\section{Resultaten}

Een ruime meerderheid van de zelfstandig wonende 55-plussers ontving in het voorgaande jaar geen hulp of zorg vanwege gezondheidsproblemen (tab. 1). Turkse en Marokkaanse 55-plussers ontvingen significant vaker (respectievelijk $34 \%$ en $31 \%$ ) een vorm van hulp dan Antilliaanse of autochtoon Nederlandse senioren (respectievelijk 18\% en 20\%). Marokkaanse se- nioren verschilden tevens significant van Surinaamse senioren (respectievelijk 31\% versus 26\%). Daar is niet mee gezegd dat Turkse en Marokkaanse 55-plussers ook vaker hulp of zorg van een professionele hulp ontvingen. Senioren met een Marokkaanse achtergrond kregen significant minder vaak hulp van professionals (8\%) dan 55-plussers van Surinaamse of autochtone afkomst (respectievelijk $15 \%$ en $11 \%$ ). Wel ontving ruim een op de vijf Marokkaanse of Turkse senioren informele hulp van familie, vrienden of bekenden. Dat is een groter aandeel dan in de andere groepen, waar circa een op de tien dergelijke hulp kreeg en het verschilt significant van Antilliaanse en autochtone senioren en voor Marokkaanse 55-plussers ook van Surinaamse senioren.

Hoe laten de gevonden verschillen tussen de herkomstgroepen zich verklaren? Uit tab. 2 blijkt dat diverse kenmerken en factoren waarvan bekend is dat ze samenhangen met het gebruik van zorg en ondersteuning niet gelijk verdeeld zijn over de herkomstgroepen. De gemiddelde leeftijd varieert van 64 jaar voor respondenten van Antilliaanse komaf tot 68 jaar voor respondenten met een Nederlandse achtergrond. De Antilliaanse 55-plussers zijn significant jonger dan de autochtone, Turkse en Marokkaanse senioren (niet in de tabel). Ook de Surinaamse 55plussers zijn significant jonger dan degenen met een Nederlandse achtergrond. De populaties Marokkaanse en autochtone 55-plussers bestaan voor minder dan de helft uit vrouwen (37\% en $48 \%$ ); bij de andere herkomstgroepen zijn vrouwen in de meerderheid. Dit is een significant verschil. Op zowel fysieke als psychische gezondheid scoren de Turkse senioren het slechtst en de Nederlandse senioren het best. Deze verschillen zijn in vrijwel alle gevallen significant, met uitzondering van de psychische gezondheid van Nederlandse senioren in vergelijking met Antilliaanse senioren (niet in de tabel). De SF-12scores van de Surinaamse en Antilliaanse 55-plussers verschillen niet significant van elkaar. Circa driekwart van de Turkse en Marokkaanse senioren heeft hooguit basisonderwijs genoten. Binnen de andere herkomstgroepen ligt het opleidingsniveau meer verspreid. De seniorengroepen met een migratieachtergrond behoren relatief vaak tot de laagste inkomensgroepen. Van de Surinaamse en Antilliaanse 55-plussers woont ruim een derde alleen. Onder de andere herkomstgroepen varieert dat van een op de acht (Marokkaans) tot iets minder dan een kwart (autochtoon). Senioren die niet alleen wonen leven doorgaans samen met in ieder geval een partner en soms ook een of meer kinderen (niet in de tabel).

Draagt de herkomst van zelfstandig wonende 55plussers bij aan de verklaring van hun gebruik van thuiszorg en informele hulp? Tab. 3 toont de resultaten van het sequentiële logit-model. Wanneer we het ontvangen van hulp vergelijken met het ontvangen van geen enkele hulp (eerste stap), dan zien we dat 75-plussers een grotere kans hebben dat ze hulp 
Tabel 2 Persoonskenmerken, gezondheidskenmerken en hulpbronnen van respondenten, naar herkomst, 2015 en 2013 (in procenten, gemiddelde leeftijd in jaren, gemiddelde score SF-12)

\begin{tabular}{|c|c|c|c|c|c|c|}
\hline & Turks & Marokkaans & Surinaams & Antilliaans & Autochtoon & Significant $^{\mathrm{a}}$ \\
\hline Aantal (n) (gewogen) & 128 & 154 & 250 & 196 & 414 & \\
\hline Gemiddelde leeftijd (SE) & $65,8(0,78)$ & $65,8(0,86)$ & $64,7(0,53)$ & $63,5(0,51)$ & $67,6(0,44)$ & ** \\
\hline Leeftijdsklassen & & & & & & ** \\
\hline 55-64 jaar & 51 & 49 & 59 & 63 & 42 & \\
\hline 65-74 jaar & 35 & 34 & 27 & 30 & 35 & \\
\hline 75 jaar of ouder & 14 & 17 & 14 & 6 & 23 & \\
\hline Geslacht & & & & & & * \\
\hline vrouw & 53 & 37 & 56 & 56 & 48 & \\
\hline man & 47 & 63 & 44 & 44 & 52 & \\
\hline Opleidingsniveau & & & & & & ** \\
\hline hoogstens basisonderwijs & 79 & 75 & 29 & 22 & 23 & \\
\hline vmbo/mavo & 5 & 8 & 23 & 29 & 31 & \\
\hline $\mathrm{mbo} / \mathrm{havo} / \mathrm{vwo}$ & 13 & 9 & 27 & 33 & 21 & \\
\hline hbo/wo & 3 & 8 & 22 & 16 & 24 & \\
\hline \multicolumn{7}{|l|}{ Score SF- $12^{b}$} \\
\hline fysieke gezondheid ${ }^{b}(\mathrm{SE})$ & $41,0(2,6)$ & $50,2(3,0)$ & $59,9(2,0)$ & $62,2(2,3)$ & $68,8(1,4)$ & ** \\
\hline psychische gezondheid $^{\mathrm{b}}$ (SE) & $58,0(2,2)$ & $64,9(1,9)$ & $69,7(1,6)$ & $73,3(1,6)$ & $76,7(1,0)$ & ** \\
\hline Besteedbaar huishoudinkomen 2013 & & & & & & ** \\
\hline eerste kwartiel & 42 & 22 & 33 & 40 & 15 & \\
\hline tweede kwartiel & 28 & 43 & 27 & 20 & 28 & \\
\hline derde kwartiel & 21 & 18 & 20 & 20 & 24 & \\
\hline vierde kwartiel & 9 & 18 & 19 & 20 & 33 & \\
\hline Huishoudsamenstelling & & & & & & ** \\
\hline alleenwonend & 19 & 13 & 34 & 35 & 23 & \\
\hline met anderen & 81 & 87 & 66 & 65 & 77 & \\
\hline
\end{tabular}

ontvangen dan 55- tot en met 64-jarigen (OR 5,17, 95\%-BI 3,09-8,67). Daarnaast neemt de kans op hulp af naarmate de fysieke gezondheid beter is (OR 0,95, 95\%-BI 0,94-0,96). Dat is plausibel omdat 75-plussers en mensen met een slechtere fysieke gezondheid vaker een hulpbehoefte zullen hebben. Het hebben van een of meer huisgenoten (OR 0,38, 95\%-BI 0,23-0,63), van een vbo-/mavo-opleiding (ten opzichte van hoogstens basisonderwijs) (OR 0,56, 95\%-BI 0,32-0,97) en van een inkomen in het tweede kwartiel (ten opzichte van het eerste kwartiel) (OR 0,47, 95\%-BI 0,28-0,78) verkleinen de kans op het ontvangen van hulp. Voor herkomst van de senioren worden geen significante resultaten gevonden, wat wil zeggen dat niet uitgesloten kan worden dat de gevonden resultaten op toeval berusten.

Wanneer we het ontvangen van professionele hulp vergelijken met het enkel krijgen van hulp van familie, vrienden en bekenden (tweede stap), dan valt op dat de fysieke gezondheid geen rol meer speelt (OR 0,99, 95\%-BI 0,98-1,01). De fysieke gezondheid houdt dus verband met het wel of niet ontvangen van hulp, maar vervolgens niet met de bron van die hulp. Wel vergroot een hogere leeftijd (65-plus) de kans op professionele hulp versus informele hulp, terwijl het hebben van een huisgenoot (OR 0,32, 95\%-BI 0,16-0,61) en een hoger inkomen die kans verkleinen. Daarnaast bestaan in de tweede stap verbanden met herkomst: Marokkaanse, Turkse en Antilliaanse senioren die hulp ontvangen hebben een kleinere kans op professionele hulp dan informele hulp in vergelijking tot autochtone senioren, ook wanneer rekening wordt gehouden met onder meer hun leeftijd en gezondheid.

\section{Besluit}

Zelfstandig wonende 55-plussers met een Turkse of Marokkaanse achtergrond ontvingen in 2014-2015 vaker een vorm van hulp vanwege gezondheidsproblemen dan 55-plussers van Nederlandse herkomst. Marokkaanse senioren ontvingen echter minder vaak professionele hulp en zowel Turkse als Marokkaanse senioren ontvingen vaker (enkel) informele hulp. De verschillen laten zich ten dele verklaren door verschillen in leeftijd, fysieke gezondheid, opleidingsniveau, de aanwezigheid van een huisgenoot en de relatieve hoogte van het inkomen. Daarnaast houdt herkomst zelfstandig verband met de bron van de hulp wan- 
Tabel 3 Het sequentiële logit-model voor het ontvangen van hulp (eerste stap) en de bron van de ontvangen hulp (tweede stap), zelfstandig wonende 55-plussers, 2015 (oddsratio's, 95\%-betrouwbaarheidsinterval) $^{\mathrm{a}}$

\begin{tabular}{|c|c|c|c|c|}
\hline & \multicolumn{2}{|c|}{ Eerste stap: wel hulp versus geen hulp } & \multicolumn{2}{|c|}{$\begin{array}{l}\text { Tweede stap: hulp van een professional versus hulp van familie, vrien- } \\
\text { den, bekenden }\end{array}$} \\
\hline & \multicolumn{2}{|c|}{$n=1122$} & \multicolumn{2}{|c|}{$n=256$} \\
\hline & $\mathrm{OR}$ & $95 \%-B \mid$ & $\mathrm{OR}$ & $95 \%-B I$ \\
\hline Leeftijd (55-64 jaar) & 1 & & 1 & \\
\hline $65-74$ jaar & 1,52 & $0,98-2,36$ & $2,87^{\star \star}$ & $1,31-6,29$ \\
\hline 75 jaar of ouder & $5,17^{\star \star \star}$ & $3,09-8,67$ & $2,83^{\star \star}$ & $1,38-5,77$ \\
\hline Geslacht (man) & 1 & & 1 & \\
\hline vrouw & 1,37 & $0,92-2,05$ & 1,26 & $0,65-2,42$ \\
\hline $\begin{array}{l}\text { Opleidingsniveau (hoogstens basisonder- } \\
\text { wijs) }\end{array}$ & 1 & & 1 & \\
\hline $\mathrm{vbo/mavo}$ & $0,56^{*}$ & $0,32-0,97$ & 0,43 & $0,17-1,05$ \\
\hline mbo/havo/vwo & 0,65 & $0,37-1,13$ & 1,54 & $0,55-4,28$ \\
\hline hbo/wo & 0,64 & $0,33-1,23$ & 1,01 & $0,37-2,78$ \\
\hline Herkomst (autochtoon) & 1 & & 1 & \\
\hline Marokkaans & 0,99 & $0,54-1,84$ & $0,17^{\star \star}$ & $0,06-0,49$ \\
\hline Turks & 0,58 & $0,30-1,10$ & $0,15^{\star \star}$ & $0,05-0,48$ \\
\hline Surinaams & 1,01 & $0,59-1,73$ & 0,53 & $0,23-1,22$ \\
\hline Antilliaans & 0,56 & $0,28-1,11$ & $0,34^{*}$ & $0,13-0,91$ \\
\hline Fysieke gezondheid ${ }^{b}$ & $0,95^{\star \star \star}$ & $0,94-0,96$ & 0,99 & $0,98-1,01$ \\
\hline Psychische gezondheid ${ }^{b}$ & 1,00 & $0,99-1,01$ & 0,99 & $0,97-1,00$ \\
\hline Huishoudsamenstelling (alleenwonend) & 1 & & 1 & \\
\hline een of meer huisgenoten & $0,38^{\star \star \star}$ & $0,23-0,63$ & $0,32^{\star *}$ & $0,16-0,61$ \\
\hline $\begin{array}{l}\text { Besteedbaar huishoudinkomen } 2013 \\
\text { (eerste kwartiel) }\end{array}$ & 1 & & 1 & \\
\hline tweede kwartiel & $0,47^{\star \star}$ & $0,28-0,78$ & 0,56 & $0,26-1,22$ \\
\hline derde kwartiel & 0,86 & $0,47-1,58$ & $0,24^{\star \star}$ & $0,09-0,66$ \\
\hline vierde kwartiel & 0,85 & $0,43-1,68$ & $0,23^{\star \star}$ & $0,08-0,65$ \\
\hline Constante & $7,87^{\star \star \star}$ & $3,41-18,15$ & $7,09^{\star \star}$ & $2,02-24,81$ \\
\hline
\end{tabular}

neer men hulp ontvangt, maar niet met het wel of niet ontvangen van hulp. Wanneer rekening wordt gehouden met diverse kenmerken van de senioren leeftijd, geslacht, fysieke en psychische gezondheid, opleidingsniveau, huisgenoten en inkomensniveau - blijkt dat Turkse, Marokkaanse en Antilliaanse 55plussers die hulp ontvangen een kleinere kans hebben op professionele hulp dan (enkel) informele hulp in vergelijking met autochtone senioren. Voor senioren met een Surinaamse achtergrond werden geen significante verschillen gevonden. De uitkomsten liggen in lijn met die van eerdere onderzoeken in Nederland en Denemarken [1, 6-10].

Bij de hier gebruikte gegevens vallen enkele kanttekeningen te plaatsen. Hoewel de antwoordcategorieën in de vragenlijst elkaar uitsloten, sluiten het gebruik van informele en professionele hulp elkaar in de realiteit niet uit. We hebben daarom - terecht of ten onrechte - aangenomen dat respondenten die zowel professionele als informele hulp ontvangen, hebben geantwoord dat zij professionele hulp krijgen. Dit betekent dat sommige respondenten met professionele hulp ook informele hulp ontvangen, maar niet zijn opgenomen in de cijfers voor informele hulp. Daarnaast is het belangrijk op te merken dat het aantal respondenten in de tweede stap van het sequentiële logitmodel voldoende maar relatief klein is, wat de uitkomsten mogelijk minder betrouwbaar maakt. Zoals vermeld stroken de resultaten wel met die van eerdere onderzoeken. De gegevens zijn verzameld in 2015 en betreffen de periode van februari 2014 tot half juli 2015. Voor een beter inzicht in de bestaande situatie na de stelselwijziging van 1 januari 2015 zijn recentere gegevens noodzakelijk. In 2020 vindt een nieuwe ronde van de SIM plaats, waarvan de gegevens pas na 2020 beschikbaar komen.

Op grond van de huidige gegevens valt te concluderen dat Antilliaanse, Turkse en Marokkaanse 55plussers de weg naar de professionele thuiszorg nog niet in gelijke mate weten te vinden als 55-plussers met een Nederlandse achtergrond, om welke reden dan ook. Dit verdient aandacht, omdat deze groep naar verwachting zowel in absoluut aantal als in relatief aandeel zal toenemen. Een eerste vraag is hoe 
problematisch de verschillen zijn. Onze resultaten laten immers zien dat niet-westerse senioren bij gezondheidsproblemen niet van hulp verstoken blijven. Mantelzorg vormt een belangrijke bron. Voor veel Marokkaanse en Turkse senioren zal hulp door familieleden, in eerste instantie, de voorkeur hebben of de meest vanzelfsprekende optie zijn. Professionele zorg kan echter op een bepaald moment van belang zijn om verergering van gezondheidsproblemen te voorkomen, overbelasting bij mantelzorgers te verhoeden en uiteindelijk ook kwaliteit van leven te waarborgen. Uit een onderzoek in Amsterdam blijkt dat een deel van de niet-westerse ouderen met functionele beperkingen (meer) thuiszorg wil [8]. De toegang tot de professionele thuiszorg verdient dus zeker aandacht.

Zorg- en hulpverleners, zorgaanbieders en gemeenten moeten actief stappen ondernemen om de onvervulde behoefte aan professionele zorg en ondersteuning van ouderen met een migratieachtergrond in beeld te krijgen en de informatievoorziening voor deze groep te verbeteren. Ook kenmerken van het zorgstelsel kunnen een rol spelen, zoals de indicatiestelling en de voorwaarden waaraan mensen moeten voldoen om in aanmerking te komen voor formele ondersteuning. Zo horen gemeenten bij de beoordeling van een Wmo-aanvraag mee te wegen welke hulp mantelzorgers bieden en welke hulp zij nog meer zouden kunnen bieden. De resultaten laten zien dat senioren met een niet-westerse migratieachtergrond vaker informele zorg ontvangen. Het onderzoek geeft echter geen uitsluitsel over de vraag of dat komt omdat zij meer mantelzorg tot hun beschikking hebben, omdat zij een sterkere voorkeur hebben voor het ontvangen van zorg van hun naasten of omdat ze minder vaak in aanmerking komen voor een indicatie voor professionele zorg. Vervolgonderzoek waarbij deze verschillende aspecten meegenomen worden zou het waargenomen verschil in zorggebruik beter kunnen duiden. Daarnaast laat de analyse in tab. 3 zien dat een hogere leeftijd een grotere kans op professionele hulp geeft, ongeacht de fysieke en psychische gezondheid. Senioren met een niet-westerse migratieachtergrond krijgen echter vaak op jongere leeftijd al met fysieke beperkingen en een slechtere gezondheid te maken. Mogelijk worden migranten als gevolg van de beschikbare mantelzorg en hun relatief jonge leeftijd nog onvoldoende opgemerkt of in aanmerking genomen voor professionele ouderenzorg.

Open Access This article is licensed under a Creative Commons Attribution 4.0 International License, which permits use, sharing, adaptation, distribution and reproduction in any medium or format, as long as you give appropriate credit to the original author(s) and the source, provide a link to the Creative Commons licence, and indicate if changes were made. The images or other third party material in this article are included in the article's Creative Commons licence, unless indicated otherwise in a credit line to the material. If material is not included in the article's Creative Commons licence and your intended use is not permitted by statutory regulation or exceeds the permitted use, you will need to obtain permission directly from the copyright holder. To view a copy of this licence, visit http://creativecommons.org/licenses/by/4.0/.

\section{Literatuur}

1. Schellingerhout R. Gezondheid en welzijn van allochtone ouderen. Den Haag: Sociaal en Cultureel Planbureau; 2004.

2. Fakiri F el, Bouwman-Notenboom J. Gezondheid van oudere migranten in de vier grote steden. Amsterdam: GGD Amsterdam in samenwerking met GGD Haaglanden, GGD Rotterdam-Rijnmond en Gemeente Utrecht/ Volksgezondheid; 2015.

3. Parlevliet JL, Uysal-Bozkir Ö, Goudsmit M, et al. Prevalence of mild cognitive impairment and dementia in older nonwestern immigrants in the Netherlands: a cross-sectional study. IntJ Geriatr Psychiatry. 2016;31:1040-9.

4. Conkova N, Lindenberg J. Gezondheid en welbevinden van oudere migranten in Nederland: Een narratieve literatuurstudie. Tijdschr Gerontol Geriatr. 2018;49:223-31.

5. Klokgieters S, Tilburg T van, Deeg D, et al. Gezondheidsverschillen onder oudere migranten in Nederland. Demos. 2018;34(9):4-7.

6. Poort EC, Spijker J, Dijkshoorn H, et al. Zelfredzaamheid en zorggebruik van de eerste generatie Turkse en Marokkaanse migrantenouderen. Tijdschr Gezondheidswet. 2003;81(4):202-9.

7. Denktaş S. Health and health care use of elderly immigrants in the Netherlands. (Proefschrift). Rotterdam: Erasmus Universiteit Rotterdam;2011.

8. Wieringen J van. Wie zorgt voor oudere migranten? De rol van mantelzorgers, sleutelfiguren, professionals, gemeenten en ouderen zelf. Utrecht: Pharos Expertisecentrum voor gezondheidsverschillen; 2014.

9. Hazeleger FGM, Dijkshoorn H, Buster M, et al. Verschillen in thuiszorggebruik onder Amsterdamse ouderen. Tijdschr Gezondheidswet. 2016;94(8):305-12.

10. Hansen EB. Older immigrants' use of public home care and residential care. Eur J Ageing. 2014;11:41-53.

11. Graaff F de, Francke A, Hasselt T van. Waarom maken terminale Turken en Marokkanen zo weinig gebruik van thuiszorg? Fact sheet. Internet. Utrecht: NIVEL; 2005. Beschikbaar via: www.nivel.nl. Geraadpleegd op 9 maart 2020.

12. Fokkema T. Interculturalisatie van de ouderenzorg: een terugblik en roep om meer onderzoek. Redactioneel. Tijdschr Gerontol Geriatr. 2011;42(1):2-6.

13. Suurmond J, Rosenmöller DL, Mesbahi $\mathrm{H}$ el, et al. Barriers in access to home care services among ethnic minority and Dutch elderly-a qualitative study. Int J Nurs Stud. 2016;54:23-35.

14. Verstappen C, Broeke J van den. Transitie van familiezorg naar gedeelde zorg. Samen zorgen voor oudere migranten. Geron. 2018;20(2):11-4.

15. Kromhout M, Kornalijnslijper N, Klerk M de. Veranderde zorg en ondersteuning voor mensen met een beperking. Landelijke evaluatie van de Hervorming Langdurige Zorg. Den Haag: Sociaal en Cultureel Planbureau; 2018.

16. Tuzgöl-Broekhoven A, Stam J, Atalikyayi R. Zorgen voor burgers. Onderzoek naar knelpunten die burgers ervaren bij de toegang tot zorg. Internet. Den Haag: De Nationale ombudsman; 2018. Beschikbaar via: www. nationaleombudsman.nl. Geraadpleegd op 9 maart 2020 .

17. Yerden I. Tradities in de knel: zorgverwachtingen en zorgpraktijk bij Turkse ouderen en hun kinderen in Nederland. 


\section{Wetenschappelijk artikel}

Proefschrift. Amsterdam: Universiteit van Amsterdam; 2013.

18. Yerden I. Veranderingen in de zorg voor Turkse ouderen in de Nederlandse samenleving. Geron. 2014;16(4):52-5.

19. HuijnkW, Andriessen I. Integratiein zicht? Deintegratievan migranten in Nederland op acht terreinen nader bekeken. Den Haag: Sociaal en Cultureel Planbureau; 2016.

20. Andersen RM. Revisiting the behavioral model and access to medical care: does it matter? J Health Soc Behav. 1995;36:1-10.

21. Andersen R, Newman JF. Societal and individual determinants of medical care utilization in the United States. MilbankQ. 1973;51(1):95-124.

22. BabitschB, GohlD, LengerkeTvon. Re-revisitingAndersen's behavioral model of health services use: a systematic review of studies from 1998-2011. GMS Psychosoc Med. 2012;9:Doc11.

23. Plaisier I, KlerkM de. Zicht op zorggebruik. Ontwikkelingen inhetgebruikvan huishoudelijkehulp, persoonlijkeverzor- ging en verpleging tussen 2004 en 2011. Den Haag: Sociaal en Cultureel Planbureau;; 2015.

24. Andriessen I, Kappelhof J. Survey Integratie Migranten 2015. Verantwoording van de opzet en uitvoering van een survey onder Turkse, Marokkaanse, Surinaamse, Antilliaanse, Poolse en Somalische Nederlanders en een autochtoon Nederlandse vergelijkingsgroep. Den Haag: Sociaal en Cultureel Planbureau; 2016. Beschikbaar via: www.scp.nl. Geraadpleegd op 9 maart 2020.

25. Ware JE, Kosinski M, Keller SD. SF-12: how to score the SF-12 physical and mental health summary scales. Boston: The Health Institute; 1995.

26. Andriessen I, Gijsberts M, HuijnkW, et al. Gevlucht met weinig bagage. De leefsituatie van Somalische Nederlanders. Internet. Den Haag: Sociaal en Cultureel Planbureau; 2017. Beschikbaar via: www.scp.nl. Geraadpleegd op 9 maart 2020. 